
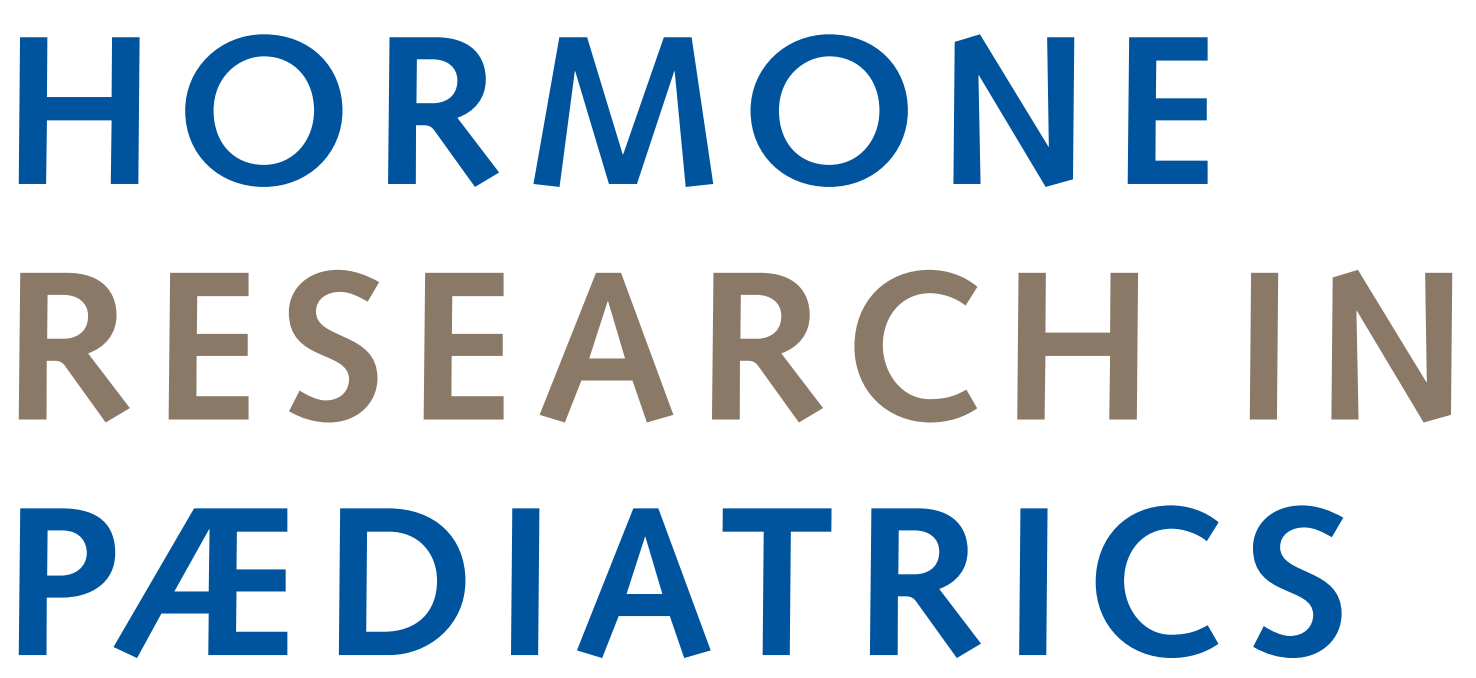

From Developmental Endocrinology to Clinical Research

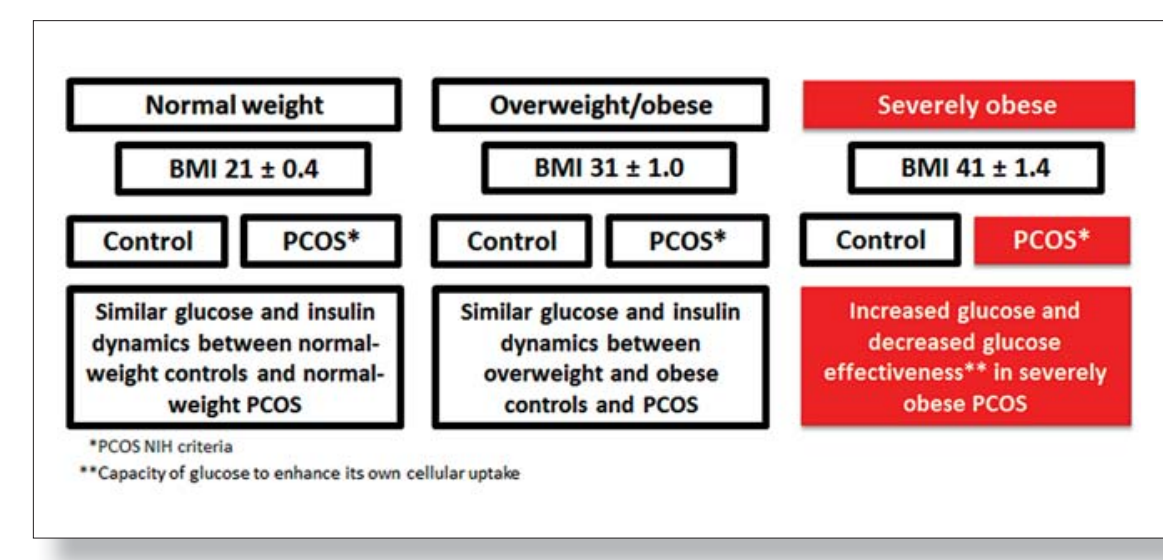

Dissecting the role of PCOS and obesity in metabolic risk 


\section{The complex endocrine-neuro-immune network condensed into one comprehensive volume}

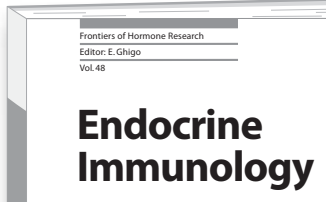

Editors

W.Savino
F. Guarald

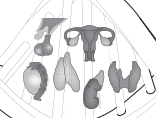

KARGER

\section{Endocrine \\ Immunology}

\author{
Editors \\ Wilson Savino \\ Federica Guaraldi
}

Endocrine Immunology

Editors: Savino, W. (Rio de Janeiro);

Guaraldi, F. (Turin)

VIII + 180 p., 19 fig., 12 in color, 11 tab., 2017

CHF 160.00 / EUR 150.00 / USD 188.00

Hard cover or online prices for

personal customers

Prices subject to change, VAT not included

EUR price for eurozone countries,

USD price for USA and Latin America only

ISBN 978-3-318-06013-3

e-ISBN 978-3-318-06014-0

Frontiers of Hormone Research, Vol. 48 Series Editors: Ghigo, E. (Turin);

Guaraldi, F. (Turin)

Listed in MEDLINE/PubMEd,

Thomson Reuters indices

Dear Librarian

I have reviewed this publication and would like to recommend it for our library.

\section{Recommended by:}

\section{Department:}

Date:

Signature:
In the last decades, several in vitro and in vivo studies have revealed the existence of a very complex network between the neuroendocrine and immune system. Important molecular mechanisms underlying these interactions, in both physiological and pathological conditions, have also been described. Indeed, hormones play a pivotal role in the development and functional regulation of the immune system - both innate and acquired responses. Immune system cells present specific hormone receptors and themselves produce some hormones, thus influencing hormone secretion. More recently, the modulation of hormone secretion has been attempted for treating associated autoimmune disorders, further supporting the strong interplay between the endocrine and immune system.

Distinguished experts, who have published extensively in their fields, have contributed comprehensive chapters to this volume. The focus is on the various aspects of endocrine-neuro-immune connections, providing an updated panorama - from basics to clinical applications - of current knowledge and still debated issues.

\section{Contents}

Preface: Savino, W.; Guaraldi, F.; Ghigo, E.

- Immune-Neuro-Endocrine Reflexes, Circuits, and Networks Physiologic and Evolutionary Implications: del Rey, A.; Besedovsky, H.O. - Inflammation and Thymus Ageing: Lepletier, A.; Isharif, A.; Chidgey, A.P.

- Intrahypophyseal Immune-Endocrine Interactions: Endocrine Integration of the Inflammatory Inputs: Renner, U.; Sapochnik, M.; Lucia, K.; Stalla, G.K.; Arzt, E. - Pituitary Autoimmunity: Guaraldi, F.; Giordano, R.; Grottoli, S.; Ghizzoni, L.; Arvat, E.; Ghigo, E.

- Prolactin: An Immunomodulator in Health and Disease: Savino, $\mathbf{w}$.

- A Novel Clinical Entity of Autoimmune Endocrinopathy: Anti-PIT-1 Antibody Syndrome: Iguchi, G.; Bando, H.; Takahashi, Y.

- Leptin, Neuroinflammation and Obesity:

Dragano, N.R.V.; Haddad-Tovolli, R.; Velloso, L.A.

- Thyroid Autoimmunity and Cancer: Felicetti, F.; Catalano, M.G.; Fortunati, N.

- Role of Cortistatin in the Stressed Immune System: Delgado, M.; Gonzalez-Rey, E.

- Steroids and Autoimmunity: Trombetta, A.C.; Meroni, M.; Cutolo, $M$.

- Endocrine Autoimmunity in Down's Syndrome: Guaraldi, F.; Rossetto Giaccherino, R.; Lanfranco, F.; Motta, G.; Gori, D.; Arvat, E.; Ghigo, E.; Giordano, R.

- The Somatotrope Growth Hormone-Releasing Hormone/Growth Hormone/ Insulin-Like Growth Factor-1 Axis in Immunoregulation and Immunosenescence: Bodart, G.; Farhat, K.; Charlet-Renard, C.; Salvatori, R.; Geenen, V.; Martens, H. - Endocrine Immunology of Chagas Disease: Savino, W.

Author Index / Subject Index 
Official Journal of

European Society for

Paediatric Endocrinology

\section{PES}

Pediatric Endocrine Society

\section{SLEP}

Sociedade Latino-Americana de

Endocrinologîa Pediátrica

HORMONE

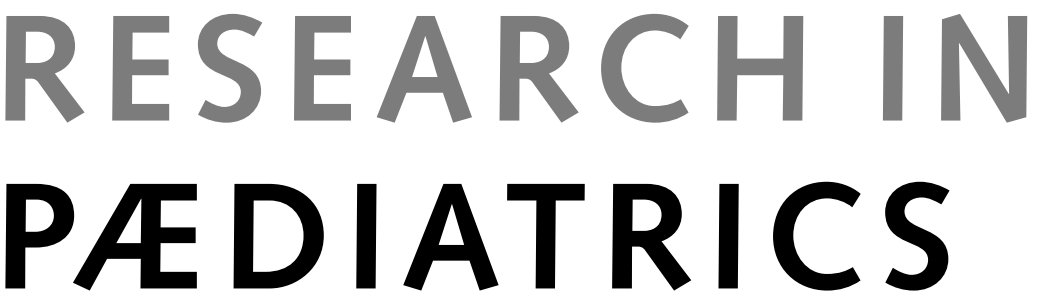

From Developmental Endocrinology to Clinical Research

Founded 1970 as "Hormones" by M. Marois

Continued by J. Girard (1976-1995); M.B. Ranke (1996-2003);

P. Czernichow (2004-2013)

\section{Editorial Board}

A. Bereket, Istanbul

J.-P. Bourguignon, Liège

F. Cassorla, Santiago

J.-P. Chanoine, Vancouver, B.C.

F. Chiarelli, Chieti

P.E. Clayton, Manchester

E. Codner, Santiago

E. Connor, Madison, Wis.

W. Cutfield, Auckland

C. Deal, Montreal, Que.

M. Donaldson, Glasgow

D.B. Dunger, Cambridge

M. Freemark, Durham, N.C.

C. Gong, Beijing

A.C.S. Hokken-Koelega, Rotterdam

R. Horikawa, Tokyo

A. Hübner, Dresden

K.Y. Loke, Singapore

C. Maffeis, Verona
M. Misra, Boston, Mass.

M.B. Ranke, Tübingen

M.A. Rivarola, Buenos Aires

S.A. Rivkees, Gainesville, Fla.

R.G. Rosenfeld, Los Altos, Calif.

P. Saenger, New York, N.Y.

D.E. Sandberg, Ann Arbor, Mich.

M.O. Savage, London

P.W. Speiser, Lake Success, N.Y.

T. Tanaka, Tokyo

G. Van Vliet, Montreal, Que.

R. Verkauskiene, Kaunas

(Continued on next page) 
HORMONE

RESEARCH IN

PAEDIATRICS
(Continued)

ESPE Council 2017

Secretary General

P. Clayton, Manchester

Chair of Education and Training Committee

President

G. Chrousos, Athens

Chair of Strategic and Finance Committee

A.C. Hokken-Koelega, Rotterdam

Chair of Clinical Practice Committee

E. Charmandari, Athens

Chair of Corporate Liaison Board

A. Grüters-Kieslich, Berlin
R. Verkauskiene, Kaunas

Chair of Programme Organising Committee

M. Dattani, London

Chair of the Scientific Committee

S.F. Ahmed, Glasgow

Chair of Communications

Committee

G. Chrousos, Athens

\section{PES Board of Directors}

President

S. Rosenthal, San Francisco, Calif.

President-Elect

M.M.-C. Lee, Worcester, Mass.

Secretary

J.S. Fuqua, Indianapolis, Ind.

Treasurer

P. Lee, Hershey, Pa.
Past President

S. Radovick, New Brunswick, N.J.

At Large Directors

B.A. Boston, Portland, Oreg.

D. Shulman, Tampa, Fla.

M. Misra, Boston, Mass. 
HORMONE

\section{RESEARCH IN PAEDIATRICS}

\section{Aim and Scope}

Hormone Research in Paediatrics aims to provide rapid publication of clinical investigations, mini reviews and novel insights from clinical experience, as well as experimental and methodological work related to paediatric and adolescent endocrinology. Correspondence is welcome, but publication of letters is at the discretion of the editors.

\section{Submission}

Manuscripts written in English should be submitted using the online submission website at:

www.karger.com/hrp

Should you have any problems with your submission, please contact the Editorial Office:

\section{hrp@karger.com}

Prof. S. Cianfarani

S. Karger AG

Editorial Office "Hormone Research in

Paediatrics"

P.O. Box

CH-4009 Basel (Switzerland)

Tel. +4161306 1437

Fax +41613061434

They should be accompanied by a signed copyright transfer statement (please see submission website). The names and addresses of four experts in the appropriate area of research should accompany each manuscript. Selected scientist(s) will be invited to act as referee(s).

\section{Main Sections}

1. Original papers

Any original papers on hormone research are accepted; we particularly welcome papers on developmental and clinical research.

\section{Mini reviews}

Most mini reviews are submitted upon invitation. However, the editors are open to unsolicited mini reviews. Authors planning such a mini review are requested to contact the Editorial Office with an outline of the intended mini review. All mini reviews are subject to peer review. The guidelines for the mini reviews can be found at www.karger. com/hrp_guidelines\# 11.

3. Novel insights from clinical practice

We invite contributions to this section that provide novel insight into a clinical problem. We recognise the value of case reports and thus submissions can be based around a case or a number of similar cases. The most important aspect of the presentation is that it should provide a new perspective on a recognised clinical scenario or may represent an entirely new clinical condition. The novel aspects of the case(s) may be in the phenotype, the presentation, the investigation and/or the management. Manuscripts revealing novel mechanisms are of particular interest. Papers repeating known phenotypes or mutations in a novel context are not acceptable.

We propose that a highlighted box containing one or two bullet points on "Established facts" and "Novel insights" be placed on the first page of the report. This reinforce the novelty of the clinical observation. The manuscript should be presented with an abstract (up to 200 words), brief introduction, case or case series description and results, followed by a discussion. No limits on length or num- ber of references are imposed. Statements for the highlighted box should also be included.

4. Translational paediatric endocrinology

This section is aimed at attracting translational research based on experimental studies in cells or animal models that can have a potential impact on the understanding of pathophysiology and/or the management of children with endocrine diseases. The format should be the same as that used for original papers.

\section{Brief reports}

This section is aimed at attracting papers reporting preliminary research data and pilot studies.

These should be concise papers with findings of interest that can be communicated within the limits of 1,800 words, a maximum of 2 figures or tables and a maximum of 12 references. In the cover letter, the authors should explain why brief reports is the appropriate section for their manuscript.

Papers submitted to this new section will be treated with priority in the peer review process and if accepted also in the publication process

\section{Conditions}

All manuscripts are subject to editorial review. The names and addresses of six experts in the appropriate area of research should accompany each manuscript Selected scientist(s) will be invited to act as referee(s). Manuscripts are received with the explicit understanding that they are not under simultaneous consideration by any other publication. Submission of an article for publication implies the transfer of the copyright from the author to the publisher upon acceptance. Accepted papers become the permanent property of Hormone Research in Paediatrics and may not be reproduced by any means, in whole or in part, without the written consent of the publisher.

It is the author's responsibility to obtain permission to reproduce illustrations, tables, etc. from other publications.

\section{Arrangement}

Title page: The first page of each paper should indicate the title, the authors' names, the institute where the work was conducted, and a short title for use as running head.

Full address: The exact postal address of the corresponding author complete with postal code must be given at the bottom of the title page. Please also supply phone and fax numbers, as well as e-mail address.

Key words: Please supply 3-10 key words in English that reflect the content of the paper.

Abstract: Each paper needs an abstract of up to 200 words. It should be structured as follows:

Background/Aims: What is the major problem that

prompted the study?

Methods: $\quad$ How was the study done?

Results: Most important findings?

Conclusion: Most important conclusion?

Footnotes: Avoid footnotes. When essential, they are numbered consecutively and typed at the foot of the appropriate page.

Tables and illustrations: Tables and illustrations (both numbered in Arabic numerals) should be prepared on separate pages. Tables require a heading and figures a legend, also prepared on a separate page. Due to technical reasons, figures with a screen background should not be submitted. When possible, group several illustrations on one block for reproduction (max. size $180 \times 223 \mathrm{~mm}$ ) or provide crop marks.

\section{Color illustrations}

Online edition: Color illustrations are reproduced free of charge. In the print version, the illustrations are reproduced in black and white. Please avoid referring to the colors in the text and figure legends. Print edition: Up to 6 color illustrations per page can be integrated within the text at CHF 960.00 per page.

References: In the text identify references by Arabic numerals [in square brackets]. Material submitted for publication but not yet accepted should be noted as [unpublished data] and not be included in the reference list. The list of references should include only those publications which are cited in the text. Do not alphabetize; number references in the order in which they are first mentioned in the text. The surnames of the authors followed by initials should be given. There should be no punctuation other than a comma to separate the authors. Preferably, please cite all authors. Abbreviate journal names according to the Index Medicus system. Also see International Committee of Medical Journal Editors: Uniform requirements for manuscripts submitted to biomedical journals (www.icmje.org).

Examples

(a) Papers published in periodicals: Sun J, Koto $\mathrm{H}$, Chung KF: Interaction of ozone and allergen challenges on bronchial responsiveness and inflammation in sensitised guinea pigs. Int Arch Allergy Immunol 1997;112:191-195.

(b) Papers published only with DOI numbers:

Theoharides TC, Boucher W, Spear K: Serum interleukin-6 reflects disease severity and osteoporosis in mastocytosis patients. Int Arch Allergy Immunol DOI: $10.1159 / 000063858$

(c) Monographs: Matthews DE, Farewell, VT: Using and Understanding Medical Statistics, ed 3, revised. Basel, Karger, 1996.

(d) Edited books: Parren PWHI, Burton DR: Antibodies against HIV-1 from phage display libraries: Mapping of an immune response and progress towards antiviral immunotherapy; in Capra JD (ed): Antibody Engineering. Chem Immunol. Basel, Karger, 1997, vol 65, pp 18-56.

Reference Management Software: Use of EndNote is recommended for easy management and formatting of citations and reference lists.

\section{Digital Object Identifier (DOI)}

S. Karger Publishers supports DOIs as unique identifiers for articles. A DOI number will be printed on the title page of each article. DOIs can be useful in the future for identifying and citing articles published online without volume or issue information. More in formation can be found at www.doi.org.

\section{Supplementary Material}

Multimedia files and other supplementary files, directly relevant but not essential to the conclusions of a paper, enhance the online version of a publication and increase its visibility on the web. These files will undergo editorial review. The Editors reserve the right to limit the scope and length of the supplementary material. Multimedia and supplementary material should meet production quality standards for publication without the need for any modification or

\section{KARGER}

E-Mail karger@karger.com www.karger.com 


\section{RESEARCH IN PAEDIATRICS}

editing. Files should not exceed $10 \mathrm{Mb}$ in size. Figures and tables need to have titles and legends, and all files should be supplied separately and labeled clearly. All supplementary material should be referred to in the main text. A DOI number will be assigned to supplementary material and it will be hosted online at https://karger.figshare.com under a CC BY license. Authors will be charged a processing fee of $\mathrm{CHF}$ 250.00 for supplementary material.

\section{Self-Archiving/Green Open Access}

Karger permits authors to archive their pre-prints (i.e. pre-peer review) or post-prints (i.e. accepted manuscript after peer review but before production) on their personal or their institution's internal website. In addition, authors may post their accepted manuscripts in public Open Access repositories and scientific networks (e.g. ResearchGate or Mendeley) no earlier than 12 months following publication of the final version of their article. For all self-archiving, the posted manuscripts must:

- Be used for noncommercial purposes only

- Be linked to the final version on www.karger.com

- Include the following statement:

"This is the peer-reviewed but unedited manuscript version of the following article: [insert full citation, e.g. Cytogenet Genome Res 2014;142:227238 (DOI: 10.1159/000361001)]. The final, published version is available at http://www.karger. com/?doi=[insert DOI number]."

It is the author's responsibility to fulfill these requirements.

For papers published online first with a DOI number only, full citation details must be added as soon as the paper is published in its final version. This is important to ensure that citations can be credited to the article.

Manuscripts to be archived in PubMed Central due to funding requirements will be submitted by Karger on the author's behalf (see Funding Organizations [NIH etc.]).
For self-archiving Author's Choice ${ }^{\mathrm{TM}}$ (Gold Open Access) articles, see Author's Choice ${ }^{\mathrm{TM}}$.

\section{Author's Choice ${ }^{\mathrm{TM}}$}

Karger's Author's Choice ${ }^{\mathrm{TM}}$ service broadens the reach of your article and gives all users worldwide free and full access for reading, downloading and printing at www.karger.com. The option is available for a onetime fee of CHF 3,000.00, which is a permissible cost in grant allocation. More information can be found at www.karger.com/authors choice.

The final, published version of the article may be posted at any time and in any repository or on other websites, in accordance with the relevant Creative Commons license. Reposted Open Access articles must:

- Follow the terms of the relevant Creative Commons license

- Be linked to the final version on www.karger.com - Include the following statement:

"The final, published version of this article is available at http://www.karger.com/?doi=[insert DOI number]."

It is the author's responsibility to fulfill these requirements.

For papers published online first with a DOI number only, full citation details must be added as soon as the paper is published in its final version. This is important to ensure that citations can be credited to the article.

\section{Funding Organizations (NIH etc.)}

The U.S. National Institutes of Health (NIH) Public Access Policy mandates that accepted, peer-reviewed manuscripts are archived in its digital database, PubMed Central (PMC), within 12 months of the official publication date. As a service to authors, Karger submits NIH-funded articles to PMC on behalf of the authors immediately upon publication. The NIH assigns a PMCID within approximately 1 month and the manuscript will appear in PMC af- ter a 12-month embargo. For authors making their paper Open Access through Author's Choice ${ }^{\mathrm{TM}}$, the embargo will be overridden, thereby accelerating the accessibility of the article. Karger also complies with other funders' requirements (including Wellcome Trust and RCUK) for submission to PMC. Authors should include information on their grants in the Acknowledgements section of their papers.

\section{Page Charges}

There is no page charge for papers of 4 or fewer printed pages (including tables, illustrations and references). Each additional complete or partial page is charged to the author at CHF 650.00. The allotted size of a paper is equal to approx. 12 manuscript pages (including tables, illustrations and references). As the page charges are waived in any case for the first paper each year to be published by a member of ESPE or PES, authors who are members of the ESPE or PES should so indicate on the title page.

\section{Proofs}

Unless indicated otherwise, a PDF for correction is sent to the corresponding author and should be returned with the least possible delay. Alterations other than the correction of printer's errors are charged to the author.

\section{E-pub First}

All articles are published electronically ahead of print with a DOI number and are supplemented later with the definite reference of the printed version. The articles become available immediately after the authors' approval to publication, with the added advantage of being citable much earlier than in print. Authors can influence the time of appearance by promptly returning the proofs.

\section{Reprints}

Order form and price list is sent with the PDF. Orders submitted after the issue is printed are subject to considerably higher prices.

\section{KARGER}




\section{HORMONE RESEARCH IN PAEDIATRICS}

ISSN Print Edition: 1663-2818

ISSN Online Edition: 1663-2826

Journal Homepage: www.karger.com/hrp

Publication Data: Hormone Research in Paediatrics is published 12 times a year. Volumes 87 and 88 , each with 6 issues, appear in 2017

Copyright: (c) 2017 S. Karger AG, Basel (Switzerland). All rights reserved. No part of this publication may be translated into other languages, reproduced or utilized in any form or by any means, electronic or mechanical including photocopying, recording, microcopying, or by any information storage and retrieval system, without permission in writing from the publisher.

Disclaimer: The statements, opinions and data contained in this publication are solely those of the individual authors and contributors and not of the publisher and the editor(s). The appearance of advertisements in the journal is not a warranty, endorsement, or approval of the products or services advertised or of their effectiveness, quality or safety. The publisher and the editor(s) disclaim responsibility for any injury to persons or property resulting from any ideas, methods, instructions or products referred to in the content or advertisements.
Subscription Rates: Subscriptions run for a full calendar year. Prices are given per year. Personal subscription:

Print or Online

CHF 2035.00

EUR 1834.00

Print+Online combined CHF 2135.00

EUR 1914.00

USD 2320.00

postage and handling (added to print and print+online)

CHF 96.00 Europe, CHF 139.20 Overseas

EUR 86.40

USD 134.40

Institutional subscription

Print or Onlin

CHF 4070.00

EUR 3667.00

Print+Online combined

USD 4424.00

CHF 4681.00

EUR 4217.00

USD 5088.00

postage and handling (added to print and print+online)

CHF 120.00 Europe, CHF 174.00 Overseas

EUR 108.00

USD 168.00

Discount subscription prices:

International Society for Pediatric and Adolescent

Diabetes (ISPAD); Schweizerische Gesellschaft für

Endokrinologie; Asia Pacific Pediatric Endocrine

Society (APPES).

Subscription included in membership fee for

members of the European Society for Paediatric

Endocrinology (ESPE), the Pediatric Endocrine

Society (PES) and the Sociedade Latino-

Americana de Endocrinologia Pediátrica (SLEP).
Back Volumes and Single Issues: Information on availability and prices of single print issues and print or electronic back volumes can be obtained from Customer Service atservice@karger.com.

Bibliographic Indices: This journal is regularly listed in bibliographic services, including Current Contents ${ }^{\circledR}$ and PubMed/MEDLINE.
Subscription Orders:

Orders can be placed at agencies, bookstores, directly with the Publisher

\section{S. Karger AG}

Medical and Scientific Publishers

Allschwilerstrasse 10

$\mathrm{CH}-4009$ Basel

Switzerland

$\mathrm{t}:+41613061111$

f: +41613061234

e: karger@karger.com

w: www.karger.com

(for courier services only:

Allschwilerstrasse 10

CH-4055 Basel) or further Karger offices

or representatives:

Germany

S. Karger GmbH

Postfach

79095 Freiburg

Deutschland

(Hausadresse: Wilhelmstrasse 20A

79098 Freiburg)

t: +49761452070

$\mathrm{f:} \quad+497614520714$

e: information@karger.de

w: www.karger.de

Japan

Karger Japan, Inc

Shiba Daimon Asahi Bldg. 2F

1-2-23 Shiba Daimon

Minato-ku

Tokyo 105-0012

apan

$\mathrm{t}:+81364356242$

f: +81364356244

e: publisher@karger.jp

w: www.karger.jp
USA

S. Karger Publishers, Inc

26 West Avon Road

P.O. Box 529

Unionville, CT 0608

USA

Toll free: +18008285479

t: +18606757834

f: +18606757302

e: kargerusa@karger.com

France

Enter \& Read

Albertine Luginbuhl

23, rue du Départ, boite 37

75014 Paris

France

t: $+33(0) 681047685$

e: albertineluginbuhl@orange.fr

South East Asia, China and Taiwan Karger Regional Office (Malaysia) Level 28-03-03A, PJ Exchange

No. 16A, Persiaran Barat

46050 Petaling Jaya

Selangor Darul Ehsan

Malaysia

t: +60379620158

f: +60379620001

e: service@karger.cn; r.chew@karger.cn
Karger China

51F Raffles City Centre

268 Xi Zang Middle Road

Huang Pu District

Shanghai 200001

P.R. China

t: +862123127673

f: +862123127777

e: service@karger.cn

r.chew@karger.cn

w: www.karger.cn

India, Bangladesh, Sri Lanka Karger India

Plot No. 17, Yusuf Sarai Market

B.L. Glass Building, 2nd Floor

Sri Aurobindo Marg

New Delhi 110016

India

t: +911146029633

f: +911146029634

c: +919891052128

e: r.kumar@kargerindia.com

w: www.karger.com

Change of Address:

Both old and new address should be sent

to the subscription source.

\section{KARGER}

E-Mail karger@karger.com www.karger.com
(C) 2017 S. Karger AG, Basel

The Journal Home Page is available at:

www.karger.com/hrp 


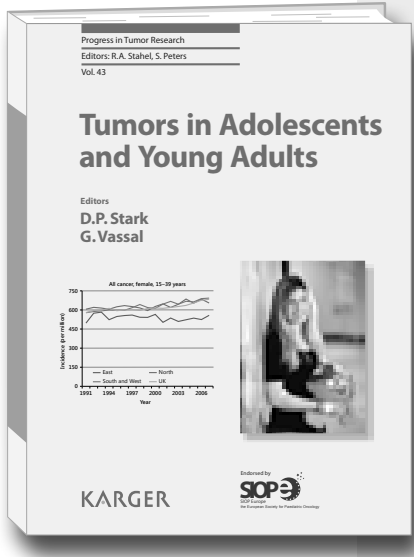

\title{
Tumors in Adolescents and Young Adults
}

\author{
Editors \\ Daniel P. Stark \\ Gilles Vassal
}

Tumors in Adolescents and Young Adults Editors: Stark, D.P. (Leeds); Vassal, G. (Villejuif) $X+146$ p., 15 fig., 9 in color, 19 tab., 2016 CHF 198.00 / EUR 185.00 / USD 233.00 Hard cover or online prices for personal customers

Prices subject to change, VAT not included EUR price for eurozone countries, USD price for USA and Latin America only

ISBN 978-3-318-05911-3

e-ISBN 978-3-318-05912-0

Progress in Tumor Research, Vol. 43 Series Editors: Stahel, R.A. (Zurich); Peters, S. (Lausanne)

ISSN 2296-1895 / e-ISSN 2296-1887

Listed in MEDLINE/PUbMed

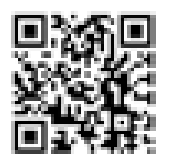

Dear Librarian

I have reviewed this publication and would like to recommend it for our library. Recommended by:

Department:

Date:

Signature:

Orders may be placed with any bookshop, subscription agency, directly with the publisher or through a Karger distributor.
The field of adolescents and young adults (AYA) oncology is experiencing a very challenging time. This book is a guide to the key issues for any clinician and health professional managing AYA with cancer in Europe. Emphasis is on collaboration between adult and pediatric specialists. Authors present their perception of the current state of the most prominent primary issues in AYA oncology.

Chapters cover cross-cutting issues such as disease epidemiology, systems of care, access to innovative therapy and late effects of treatment and survivorship for AYA-onset cancers. There are discussions of the latest developments and the most important cancer types in AYA, including the shared perspectives of adult and pediatric specialists. Throughout the book recurrent challenges to the AYA community are exposed and solutions proposed.

Tumors in Adolescents and Young Adults is highly recommended to any oncologist or hematologist treating patients aged 15 to 39 diagnosed with cancer. It will also be of interest to other members of the multidisciplinary teams involved with this patient group.

\section{Contents}

Preface: Stark, D.P.; Vassal, G.

\section{Cross-Cutting Issues}

- Epidemiology of Adolescents and Young Adults with Cancer in Europe: Desandes, E.; Stark, D.P.

- Supportive Care: Olsen, P.R.; Lorenzo, R.

- Long-Term Follow-Up and Survivorship: Tsirou, A.; Hjorth, L.

- Increasing Access to Clinical Trials and Innovative Therapy for Teenagers and Young Adults with Cancer - A Multiple Stakeholders and Multiple

Steps Process: Gaspar, N.; Fern, L.

- Collaboration and Networking: Husson, 0.;

Manten-Horst, E.; van der Graaf, W.T.A.

\section{Specific Illnesses}

- Adult Cancers in Adolescents and Young Adults: Laurence, V.; Marples, M.; Stark, D.P.

- Pediatric Cancers and Brain Tumors in Adolescents and Young Adults: McCabe, M.G.; Valteau-Couanet, D.

- Leukemia: Juliusson, G.; Hough, R.

- Lymphoma in Adolescents and Young Adults: Brugières, L.; Brice, $P$.

- Germ Cell Tumors in Adolescents and Young Adults: Calaminus, G.; Joffe, J.

- Sarcomas of Soft Tissue and Bone: Ferrari, A.; Dirksen, U.; Bielack, $\mathrm{S}$.

Author Index

Subject Index 


\section{Contents}

See the journal website for contents

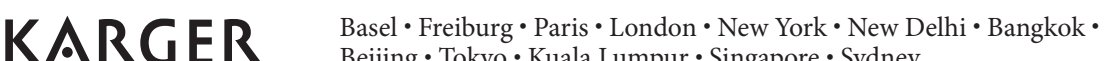
Beijing $\cdot$ Tokyo $\cdot$ Kuala Lumpur $\cdot$ Singapore $\cdot$ Sydney 


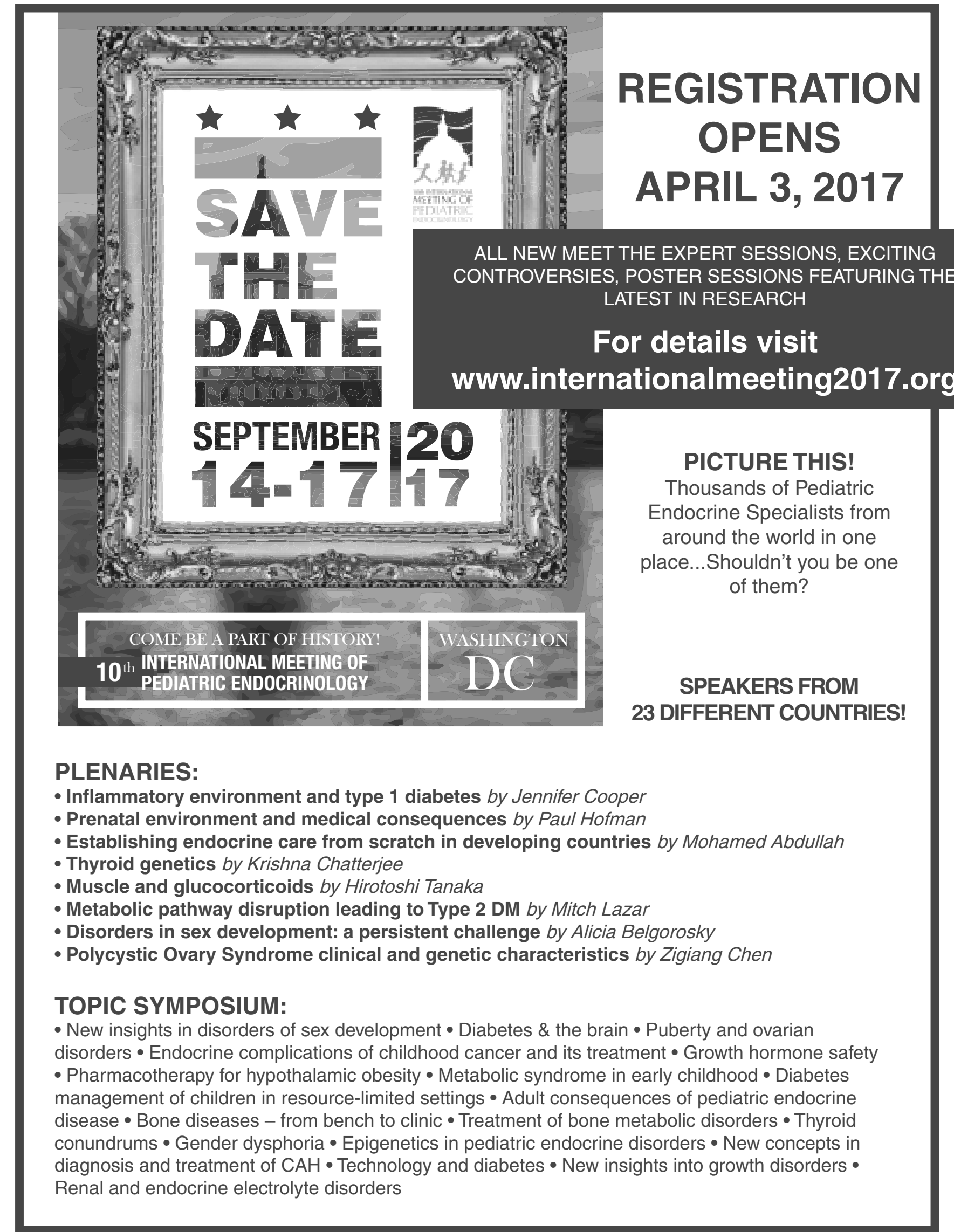




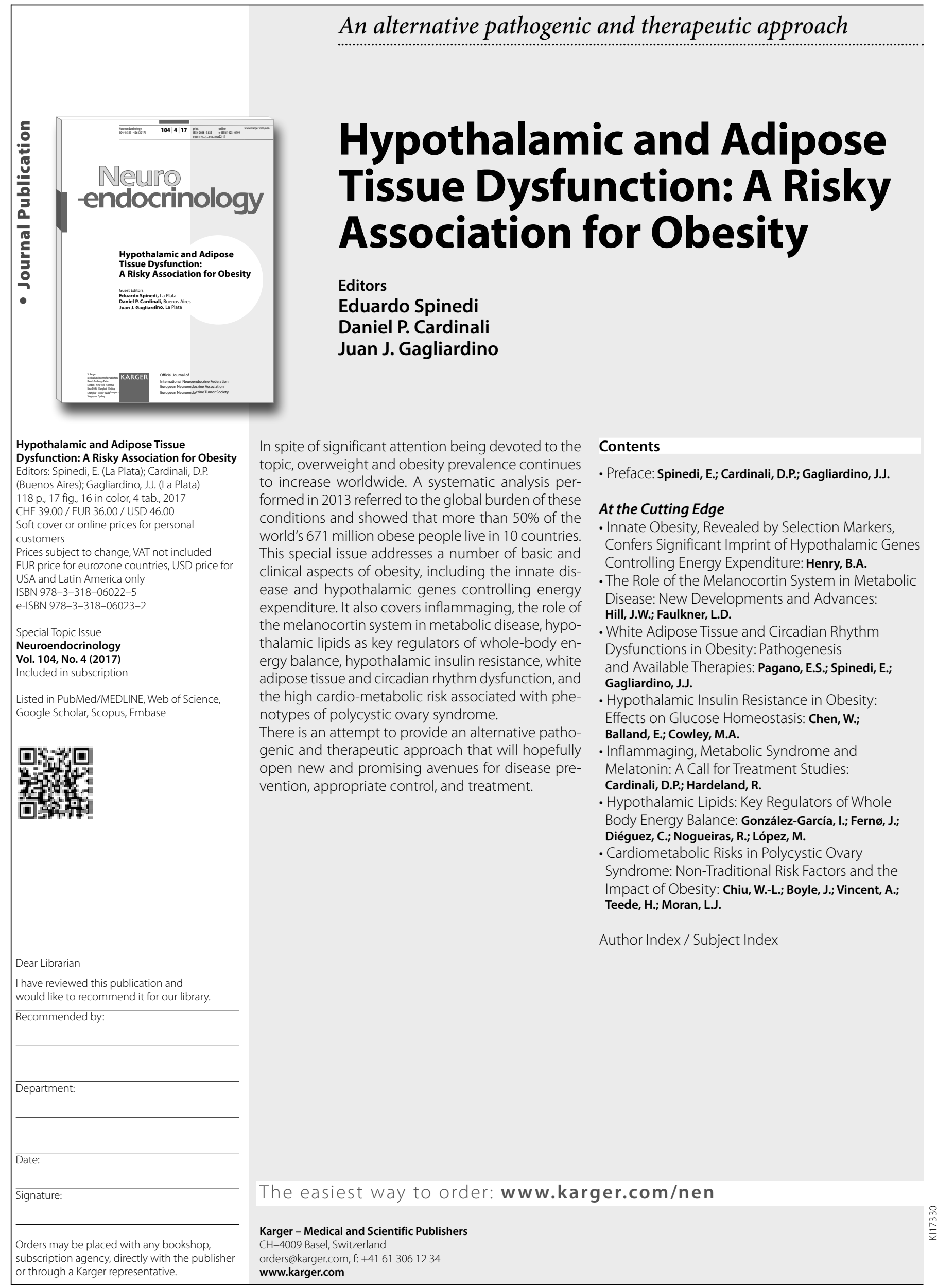




\section{Bridging computer science and biomedicine}

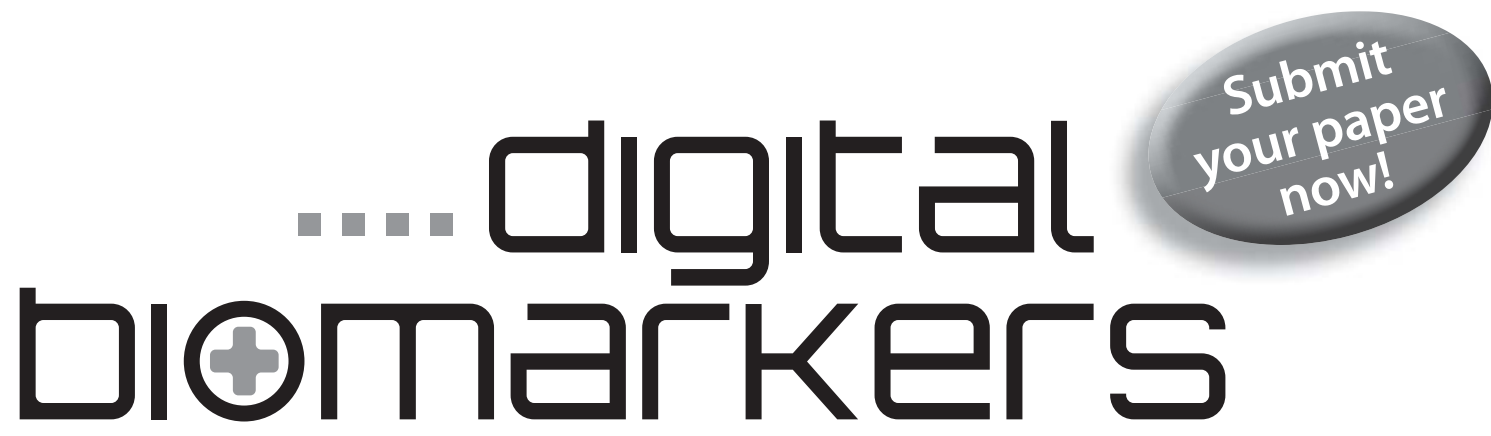

Editor-in-Chief

E. R. Dorsey, Rochester, N.Y.

Section Editor

"Network of Digital Evidence (NODE)"

A. Atreja, New York, N.Y.

Advisory Board

M. Frasier, New York, N.Y.

E. Hafen, Zurich

J. Hixson, San Francisco, Calif.

D. Karlin, Boston, Mass.

J. Kvedar, Boston, Mass.

M. Little, Birmingham

K. Mandl, Boston, Mass.

W.J. Marks Jr., San Francisco, Calif.

M. Rebhan, Basel

T. Schwede, Basel

J. Wilbanks, Seattle, Wash.

\section{Digital Biomarkers}

Founded: 2017

Category: Clinical Research

Fields of Interest: Bioinformatics, Digital Medicine www.karger.com/dib

- peer-reviewed

- fast online publication

- no article processing charge

- access to data, algorithms and app-repositories
Digital biomarkers are defined as objective, quantifiable physiological and behavioral data that are collected and measured by means of digital devices such as portables, wearables, implantables or digestibles. The data collected is typically used to explain, influence and/or predict health-related outcomes. Digital biomarkers also represent an opportunity to capture clinically meaningful, objective data.

Multidisciplinary in design, this innovative open access journal bridges the disciplines of computer science, engineering, informatics, biomedicine, regulatory science and digital evidence. Papers are published within 60 days of submission and the inclusion of videos or other visual materials is supported. Moreover, Digital Biomarkers provides and supports access to (raw) data, algorithms and app-repositories linked to the articles published in the journal. 


\section{HORMONE \\ RESEARCH IN \\ PAEDIATRICS}

\section{Original Papers}

359 Alterations in Glucose Effectiveness and Insulin Dynamics: Polycystic Ovary Syndrome or Body Mass Index

Vuguin, P.; Sopher, A.B.; Roumimper, H.; Chin, V.; Silfen, M.; McMahon, D.J.; Fennoy, I.; Oberfield, S.E. (New York, NY)

368 The Influence of the Manner of Performing the Thyroid Ultrasound Examination on the Reliability of the Assessment of the Thyroid Size in School-Aged Children

Zygmunt, A.; Adamczewski, Z.; Zygmunt, A.; Karbownik-Lewinska, M.; Lewinski, A. (Lodz)

377 Predictors of Loss to Follow-Up among Children with Type 2 Diabetes

Shoemaker, A. (Nashville, TN); Cheng, P.; Gal, R.L.; Kollman; C. (Tampa, FL); Tamborlane, W.V. (New Haven, CT);

Klingensmith, G.J. (Aurora, CO); Clements, M.A. (Kansas City, MO); Hannon, T.S. (Indianapolis, IN); Heptulla, R. (Bronx, NY); Less, J. (Oklahoma City, OK); Wood, J. (Cleveland, OH) for the Pediatric Diabetes Consortium

385 Vitamin D and Albuminuria in Youth with and without Type 1 Diabetes

Nandi-Munshi, D. (Seattle, WA); Afkarian, M. (Davis, CA); Whitlock, K.B. (Seattle, WA); Crandell, J.L. (Chapel Hill, NC); Bell, R.A. (Greenville, NC); D'Agostino, R. (Winston-Salem, NC); Saydah, S. (Atlanta, GA); Mottl, A.K. (Chapel Hill, NC); Dabelea, D. (Chapel Hill, NC); Black, M.H. (Aliso Viejo, CA); Mayer-Davis, E.J., (Chapel Hill, NC); Pihoker, C. (Seattle, WA)

\section{Brief Reports}

396 Outcome of Doctors Attending the European Society for Paediatric Endocrinology Winter Schools 2008-2014

Donaldson, M.D.C. (Glasgow)

400 Insulin-Like Growth Factors and Metabolic Syndrome in Obese Children

Inzaghi, E.; Ferroli, B.B.; Fintini, D.; Grossi, A.; Nobili, V.

(Rome); Cianfarani, S. (Rome/Stockholm)

\section{Novel Insights from Clinical Practice}

405 Two Frameshift Mutations in MKRN3 in Turkish Patients with Familial Central Precocious Puberty

Simsek, E; Demiral, M. (Eskisehir); Ceylaner, S. (Ankara); Kırel, B. (Eskisehir)

412 Expanding Genetic and Functional Diagnoses of IGF1R Haploinsufficiencies

Ocaranza, P. (Santiago); Golekoh, M.C. (Detroit, MI); Andrew, S.F. (Cincinnati, OH); Guo, M.H. (Boston, MA); Kaplowitz, P. (Washington, DC); Saal, H. (Cincinnati, OH); Rosenfeld, R.G. (Portland, OR); Dauber, A. (Cincinnati, OH); Cassorla, F. (Santiago); Backeljauw, P.F.; Hwa, V. (Cincinnati, OH)

\section{Obituary}

423 Juan Jorge Heinrich, MD, PhD, 1937-2016

Bergadá, I.; Keselman, A.; Rey, R. (Buenos Aires)

after 424 Contents Vol. 87, 2017 